\title{
KONSTITUSIONALITAS MATERIELE WEDERRECHTELIJK DALAM KEBIJAKAN PEMBERANTASAN TINDAK PIDANA KORUPSI
}

\author{
Kajian Putusan Mahkamah Konstitusi Nomor 003/PUU-IV/2006
}

\section{WEDERRECHTELIJK MATERIELE CONSTITUTIONALITY IN CORRUPTION ERADICATION POLICIES}

\author{
An Analysis of Constitutional Court Decision Number 003/PUU-IV/2006
}

\author{
Ade Adhari \\ Fakultas Hukum Universitas Tarumanagara \\ Jl. Letjen S. Parman No. 1 Jakarta 11440 \\ E-mail: adea@fh.untar.ac.id atau ade_adhari@ymail.com
}

Naskah diterima: 12 Oktober 2017; revisi: 30 Juli 2018; disetujui 6 Agustus 2018

http://dx.doi.org/10.29123/jy.v11i2.260

\begin{abstract}
ABSTRAK
Putusan Nomor 003/PUU-IV/2006 menyatakan materiele wederrechtelijk dalam Undang-Undang Tindak Pidana Korupsi bertentangan dengan Pasal 28D ayat (1) UUD NRI 1945, dan tidak berlaku mengikat. Penelitian ini berupaya memahami apakah tepat atau tidak pertimbangan Mahkamah Konstitusi dalam putusan tersebut. Dalam menjawab permasalahan tersebut digunakan penelitian doktrinal, norma hukum serta asas yang melandasi lahirnya putusan tersebut. Berdasarkan hasil penelitian diketahui terdapat ketidaktepatan dalam pertimbangan Mahkamah Konstitusi. Mahkamah Konstitusi telah keliru dalam usahanya memvalidasi Penjelasan Pasal 2 ayat (1) Undang-Undang Tindak Pidana Korupsi dengan menguji berdasarkan asas legalitas yang terdapat dalam Pasal 1 ayat (1) KUHP. Padahal prinsipnya pengujian yang dilakukan oleh Mahkamah Konstitusi adalah menguji undang-undang terhadap UUD NRI 1945. Selain itu, Putusan Mahkamah Konstitusi berorientasi pada asas legalitas yang hanya mengutamakan rechtssicherheit dan mengesampingkan
\end{abstract}

keberadaan gerechtigkeit dan zweckmässigkeit. Lebih dari itu, tidak diakuinya materiele wederrechtelijk telah meniadakan eksistensi hukum yang hidup di masyarakat sebagai sumber hukum untuk menyatakan suatu perbuatan bersifat melawan hukum. Hal ini bertentangan dengan mandat Pasal 18B ayat (2) UUD NRI 1945, dan berbagai peraturan perundang-undangan yang berlaku. Dengan demikian materiele wederrechtelijk tidak bertentangan dengan kontitusi.

Kata kunci: materiele wederrechtelijk, korupsi, konstitusionalitas.

\begin{abstract}
Constitutional Court Decision Number 003/PUUIV/2006 states unlawful criminal acts (materiele wederrechtelijk) in the Anti-Corruption Law is inconsistent with Article 28D paragraph (1) of the 1945 Constitution, and not binding. Doctrinal research, legal norms and principles underlying the birth of the court decision are used in answering whether the problem
\end{abstract}


arising from the decision is justified. Based on the result of the research, there is an inaccuracy in the consideration of the Constitutional Court. The Constitutional Court has erred in its attempt to validate the Elucidation of Article 2 Paragraph (1) of Corruption Law by examining based on the legality principle contained in Article 1 paragraph (1) of the Criminal Code. Whereas in principle, what has been conducted by the Constitutional Court is a judicial review of the law against the 1945 Constitution. In addition, the Constitutional Court's decision is oriented on the principle of legality which only prioritizes legal

\section{PENDAHULUAN}

\section{A. Latar Belakang}

Saat negara Indonesia memproklamasikan sebagai negara yang merdeka, lepas dari belenggu penjajahan, maka pada saat itu pula ditetapkan tujuan nasional yang hendak diwujudkan oleh bangsa ini. Muara akhir yang hendak dicapai tersebut tertuang dalam Alinea Keempat Pembukaan UUD NRI 1945. UUD NRI 1945 sebagai konstitusi tertulis juga telah memberikan rambu bagaimana cara mencapai tujuan nasional sebagaimana dinyatakan di atas. Melalui Pasal 1 ayat (3) UUD NRI 1945 ditetapkan bahwa hukum menjadi salah satu sarana bagi negara untuk mencapai apa yang disebut sebagai tujuan nasional.

Usaha negara untuk mencapai tujuan nasional tidaklah mudah, karena negara dihadapkan pada berbagai masalah yang terjadi di berbagai bidang kehidupan, yakni budaya, sosial, politik, dan ekonomi. Salah satu masalah yang menghambat negara dalam memenuhi tujuan nasional kepada masyarakat adalah maraknya tindak pidana korupsi di Indonesia. Tidak ada kesepakatan mengenai definisi korupsi. Hal ini yang juga diungkapkan oleh Perserikatan Bangsa-Bangsa, there is no comprehensive, and certainty (Rechtssicherheit) and overrides justice (Gerechtigkeit) and utility (Zweckmässigkeit). Moreover, the unrecognized materiele wederrechtelijk has negated the existence of a living law in society as a source of law to declare unlawful acts. This is contrary to the mandate of Article 18B paragraph (2) of the 1945 Constitution and various prevailing laws and regulations. Thus, the material wederrechtelijk is not contradictory to the constitution.

Keywords: materiele wederrechtelijk, corruption, constitutionality.

universally accepted definition of corruption (United Nations, 2004: 23). Dengan demikian kalaupun ada, pengertian tersebut dapat disebut tentative definition.

Terdapat banyak pemaknaan korupsi yang diberikan oleh berbagai ahli, di antaranya Tanzy yang menyebut bahwa corruption is the intentional non-compliance with the arm 's-length principle aimed at deriving some advantage for oneself or for related individuals from this behavior (Begovic, 2005: 2).

Secara normatif tidak terdapat pengertian korupsi dalam hukum positif yang diatur dalam Undang-Undang Nomor 31 Tahun 1999 tentang Pemberantasan Tindak Pidana Korupsi jo. Undang-Undang Nomor 20 Tahun 2001 tentang Perubahan atas Undang-Undang Nomor 31 Tahun 1999 tentang Pemberantasan Tindak Pidana Korupsi. Dalam Undang-Undang Tindak Pidana Korupsi hanya terdapat batasan untuk menyatakan perbuatan yang dikualifikasi sebagai tindak pidana korupsi.

Ditinjau dari segi criminal policy, maka ditetapkannya Undang-Undang Tindak Pidana Korupsi merupakan bentuk dari kebijakan hukum pidana. Undang-undang tersebut merupakan 
usaha rasional yang ditempuh oleh negara untuk menanggulangi tindak pidana korupsi melalui sarana sanksi pidana. Praktiknya sanksi pidana untuk menanggulangi kejahatan melalui beberapa tahapan utama, dan penetapan Undang-Undang Tindak Pidana Korupsi merupakan bagian dari tahapan yang oleh Bassiouni disebut tahap formulasi (proses legislatif).

Menurut Bassiouni, tahapan-tahapan untuk fungsionalisasi hukum pidana melalui tiga tahapan utama yaitu tahap formulasi (proses legislatif), tahap aplikasi (proses peradilan/ judicial), dan tahap eksekusi (tahap administrasi) (Arief, 2012: 10).

Kebijakan formulasi dalam menanggulangi korupsi dalam Undang-Undang Tindak Pidana Korupsi berisi norma hukum pidana materiil sekaligus norma hukum pidana formal. Salah satu norma hukum pidana materiil yang muncul adalah diakuinya keberadaan unsur sifat melawan hukum formal dan materiil (formele wederrechtelijkheid dan materiele wederrechtelijkheid), sebagai dasar untuk menyatakan suatu perbuatan bersifat melawan hukum sehingga dikatakan ada tindak pidana korupsi. Hal tersebut diatur secara tegas dalam Pasal 2 ayat (1) Undang-Undang Tindak Pidana Korupsi.

Perkembangan keberadaan Pasal 2 ayat (1) Undang-Undang Tindak Pidana Korupsi, diajukan permohonan untuk diuji validitasnya dengan Pasal 28D ayat (1) UUD NRI 1945. Permohonan tersebut diajukan DD. Permohonan tersebut kemudian diputus melalui Putusan Nomor 003/PUU-IV/2006 yang menyatakan sifat melawan hukum materiil dalam Penjelasan Pasal 2 ayat (1) Undang-Undang Tindak Pidana Korupsi dinyatakan bertentangan dengan UUD NRI 1945 dan tidak mempunyai kekuatan mengikatnya. Hal tersebut dinyatakan secara tegas dalam amar putusannya, dengan dasar pertimbangan antara lain:

1. Pasal28Dayat(1)mengakui dan melindungi hak konstitusional warga negara untuk memperoleh jaminan dan perlindungan hukum yang pasti, dengan mana dalam bidang hukum pidana diterjemahkan sebagai asas legalitas yang dimuat dalam Pasal 1 ayat (1) KUHP, bahwa asas tersebut merupakan satu tuntutan akan kepastian hukum di mana orang hanya dapat dituntut dan diadili atas dasar suatu peraturan perundang-undangan yang tertulis (lex scripta) yang telah lebih dahulu ada;

2. Hal demikian menuntut bahwa suatu tindak pidana memiliki unsur melawan hukum, yang harus secara tertulis lebih dahulu telah berlaku, yang merumuskan perbuatan apa atau akibat apa dari perbuatan manusia secara jelas dan ketat yang dilarang sehingga karenanya dapat dituntut dan dipidana, sesuai dengan prinsip nullum crimen sine lege stricta;

3. Konsep melawan hukum yang secara formal tertulis (formele wederrechtelijk), yang mewajibkan pembuat undangundang untuk merumuskan secermat dan serinci mungkin merupakan syarat untuk menjamin kepastian hukum (lex certa) atau yang dikenal juga dengan istilah bestimmheitsgebot.

Pertimbangan yang dijadikan dasar untuk memutus sebagaimana disampaikan oleh Mahkamah Konstitusi mendasarkan pada Pasal 1 ayat (1) KUHP. Hal ini tentu menyalahi prinsip bahwa pengujian yang dilakukan oleh Mahkamah Konstitusi adalah pengujian undang-undang terhadap UUD NRI 1945. Selain itu, Mahkamah Konstitusi memandang Pasal 1 ayat (1) KUHP merupakan bentuk penerjemahan ketentuan Pasal 28D ayat (1) UUD NRI 1945. Padahal jelas, KUHP tidak dibangun atas dasar UUD NRI 1945, melainkan sekadar keberlakuannya didasarkan pada aturan peralihan yang terdapat dalam UUD NRI 1945. 


\section{B. Rumusan Masalah}

Berdasarkan uraian latar belakang di atas, maka rumusan masalah dalam tulisan ini adalah sudah tepatkah pertimbangan hakim dalam menilai konstitusionalitas unsur sifat melawan hukum materiil dalam Undang-Undang Nomor 31 Tahun 1999 tentang Pemberantasan Tindak Pidana Korupsi di Indonesia dalam Putusan Nomor 003/PUU-IV/2006 ditinjau dari konstitusi?

\section{Tujuan dan Kegunaan}

Tulisan ini bertujuan untuk mengetahui dan memahami konstitusionalitas keberadaan unsur sifat melawan hukum materiil yang terdapat dalam Undang-Undang Nomor 31 Tahun 1999 tentang Pemberantasan Tindak Pidana Korupsi pasca Putusan Nomor 003/PUU-IV/2006.

Kegunaan tulisan ini antara lain:

a. Memberikan kontribusi pada perkembangan hukum pidana nasional dengan mengidentifikasi eksistensi ajaran sifat melawan hukum baik formal maupun materiil dalam sistem hukum pidana nasional dan konstitusionalitasnya; dan

b. Memberikan masukan kepada pembentuk undang-undang dalam memformulasikan unsur sifat melawan hukum materiil dalam peraturan perundang-undangan di Indonesia, dan bagi hakim adalah memberikan pemahaman terkait dengan diakuinya sifat melawan hukum, baik formal maupun materiil dalam kajian teoritis dan legislatif, sehingga penting untuk menjadi tuntunan dalam memutus oleh hakim.

\section{Tinjauan Pustaka}

\section{Kebijakan Hukum Pidana terhadap Tindak Pidana Korupsi di Indonesia}

Lapenna dalam sebuah karyanya menyebutkan: penal policy is a part of the general policy of a society-...-aimed at combating crime, and it embraces all methods and measures applied for this purpose. All these remedies against crime may be divided into two main groups: measures of prevention and measures of repression (Lapenna, 2000: 10).

Definisi berikutnya disampaikan oleh Mulder dalam Arief (2014: 27), "strafrecht en politiek" adalah:

a. Garis kebijakan untuk menentukan seberapa jauh ketentuan-ketentuan pidana yang berlaku perlu diubah atau diperbaharui;

b. Apa yang dapat diperbuat untuk mencegah terjadinya tindak pidana;

c. Cara bagaimana penyidikan, penuntutan, peradilan, dan pelaksanaan pidana harus dilaksanakan.

Kebijakan hukum pidana secara sederhana dapat dimaknai sebagai usaha rasional yang ditempuh oleh negara dalam menanggulangi kejahatan dengan menggunakan sarana hukum pidana. Praktiknya kebijakan hukum pidana menurut Bassiouni melalui tiga tahapan, yakni: tahap formulasi (proses legislatif), tahap aplikasi (proses peradilan/judicial), dan tahap eksekusi (proses administrasi) (Arief, 2012: 10). Sehubungan dengan ketiga tahapan tersebut, patut untuk dicermati apa yang disampaikan oleh Arief, yaitu: "apabila perwujudan suatu sanksi pidana hendak dilihat sebagai suatu kesatuan proses dari perwujudan kebijakan melalui tahap-tahap yang 
direncanakan sebelumnya, maka tahap-tahapnya yaitu tahap formulasi oleh pembuat undangundang, tahap aplikasi oleh pengadilan dan tahap eksekusi oleh aparat pelaksana pidana. Apabila dilihat dari suatu kesatuan proses, maka tahap kebijakan legislatif merupakan tahap yang paling strategis. Dari tahap inilah diharapkan adanya suatu garis pedoman untuk tahap-tahap berikutnya."

\section{Ajaran Sifat Melawan Hukum Materiil dalam Hukum Pidana}

Arief mengemukakan sifat melawan hukum materiil atau materiel wederrechtelijkheid terdapat dua pandangan, yaitu: pertama, sifat melawan hukum materiil dilihat dari sudut perbuatannya. Hal ini mengandung arti perbuatan yang melanggar atau membahayakan kepentingan hukum yang hendak dilindungi oleh pembuat undang-undang dalam rumusan delik tertentu. Biasanya sifat melawan hukum materiil ini dengan sendirinya melekat pada delik-delik yang dirumuskan secara materiil. Kedua, sifat melawan hukum materiil dilihat dari sudut sumber hukumnya. Hal ini mengandung makna bertentangan dengan hukum tidak tertulis atau hukum yang hidup dalam masyarakat, asas-asas kepatutan atau nilai-nilai keadilan dan kehidupan sosial dalam masyarakat (Hiariej, 2016: 237).

Secara garis besar, sifat melawan hukum materiil ini masih dibagi menjadi dua, yakni dalam fungsinya yang negatif dan dalam fungsinya yang positif. Hiariej menerangkan sifat melawan hukum materiil dalam fungsinya yang negatif, berarti meskipun perbuatan memenuhi unsur delik tetapi tidak bertentangan dengan rasa keadilan masyarakat, maka perbuatan tersebut tidak dipidana. Sedangkan sifat melawan hukum materiil dalam fungsinya yang positif, mengandung arti bahwa meskipun perbuatan tersebut tidak diatur dalam peraturan perundang-undangan, namun jika perbuatan tersebut dianggap tercela karena tidak sesuai dengan rasa keadilan atau normanorma kehidupan sosial dalam masyarakat, maka perbuatan tersebut dapat dipidana (Hiariej, 2016: 243).

Sifat melawan hukum materiil dalam fungsi yang negatif juga dianut dalam praktik pengadilan di Indonesia. Sebagai misal, kasus penyalahgunaan DO Gula berdasarkan Putusan Mahkamah Agung, 8 Januari 1966, Nomor 42K/Kr/1965 (Hiariej, 2016: 243). Sifat melawan hukum materiil dalam fungsinya yang positif juga dianut dalam praktik pengadilan di Indonesia. Sebagai misal, kasus korupsi di Bank Bumi Daya dengan terdakwa Direktur Bank Bumi Daya (Hiariej, 2016: 244).

Terkait dengan ajaran sifat melawan hukum materiil, Hiariej berpandangan:

a. Sifat melawan hukum materiil dalam fungsi yang negatif adalah sebagai alasan pembenar dan oleh karena itu penulis dapat menerimanya. Hakikat dari perbuatan pidana adalah perbuatan anti sosial, sehingga jika terdapat keragu-raguan dalam pengertian di satu sisi telah memenuhi unsur delik, namun di sisi lain bertentangan dengan rasa keadilan masyarakat, maka terdakwa harus dibebaskan;

b. Sifat melawan hukum materiil dalam fungsi yang positif bertentangan dengan asas legalitas, dan oleh karenanya penulis tidak dapat menerimanya karena akan menimbulkan ketidakpastian hukum;

c. Berkaitan dengan sifat melawan hukum materiil dalam fungsi yang positif, kiranya hal ini bertetangan dengan prinsip fundamental dalam hukum pembuktian pidana yang berbunyi actori incumbit onus probandi, actore non probante, reus absolvitur. Artinya siapa yang menuntut dialah yang wajib membuktikan, jika tidak dapat dibuktikan, terdakwa harus dibebaskan. Tegasnya, jika penuntut umum dalam perkara pidana tidak 
dapat membuktikan unsur-unsur delik yang harus didakwakan kepada terdakwa (actore non probante), maka terdakwa harus diputus bebas (reus absolvitur) (Hiariej, 2016: 249)

\section{Tiga Nilai Dasar Hukum dari Radbruch}

Radbruch menyatakan bahwa setidaknya hukum harus hadir dan mengakomodir berbagai nilai, yaitu nilai keadilan, kemanfaatan, dan kepastian. Bahkan ketika hukum dihadapkan pada pertentangan antara ketiganya, maka hakim diminta untuk memilih keadilan. Pendapat Radbruch tersebut adalah sebagai berikut.

Radbruch establishes the foundation for his theory in his 1932 work, Rechtsphilosophie. He finds that law, as a cultural concept, "is the reality the meaning of which is to serve the legal value, the idea of law." Radbruch argues that the idea of law may only be Justice.......Radbruch finds that although the idea of law is Justice, this alone does not fully exhaust the concept of law. Justice, he says, "leaves open the two questions, whom to consider equal or different, and how to treat them." To complete the concept of law Radbruch uses three general precepts: purposiveness, justice, and legal certainty.... Certainly, the conflict between legal certainty and justice or between legal certainty and purposiveness is easy to imagine......In this situation alone, the emphasis on legal certainty is greatest. Although a law may be unjust in its content, it nonetheless serves at least one purpose, legal certainty........ Radbruch rejects his earlier assertion that legal certainty was the primary role of the judge and now asserts that the judge must decide first in accordance with Justice" (Leawoods, 2000).

\section{METODE}

Jenis penelitian hukum yang digunakan adalah doktrinal. Wignjosoebroto mengartikan penelitian doktrinal terdiri dari:
1. Penelitian yang berupa usaha inventarisasi hukum positif;

2. Penelitian yang berupa usaha penemuan asas-asas dan dasar falsafah (dogma/ doktrin) hukum positif; dan

3. Penelitian yang berupa usaha penemuan hukum in concreto yang layak diterapkan untuk menyelesaikan suatu perkara hukum tertentu (Wignjosoebroto, 2002: 148).

Penelitian doktrinal dipilih karena berusaha mengkaji eksistensi atau konstitusionalitas sifat melawan hukum materiil yang terdapat dalam Undang-Undang Tindak Pidana Korupsi, terutama yang terdapat dalam Putusan Nomor 003/PUUIV/2006, dan mencari tahu alasan mendasar keberadaan sifat melawan hukum dan mengapa Mahkamah Konstitusi memutus. Pendekatan dalam penelitian ini menggunakan pendekatan undang-undang dan pendekatan kasus.

\section{HASIL DAN PEMBAHASAN}

Undang-Undang Nomor 31 Tahun 1999 tentang Pemberantasan Tindak Pidana Korupsi yang kemudian mengalami perubahan dengan Undang-Undang Nomor 20 Tahun 2001 tentang Perubahan atas Undang-Undang Nomor 31 Tahun 1999 tentang Pemberantasan Tindak Pidana Korupsi, merupakan bentuk kebijakan formulasi dalam menanggulangi tindak pidana korupsi di Indonesia.

Kebijakan formulasi merupakan bagian tahapan penting dalam usaha menggunakan sanksi pidana sebagai alat mengatasi korupsi. Pada saat ingin menggunakan sanksi pidana setidaknya akan melalui tiga tahapan, yaitu: tahapan formulasi, tahapan aplikasi, dan tahapan eksekusi. Keberadaan Undang-Undang Tindak Pidana Korupsi dalam ranah formulasi menjadi bagian penting dalam penanggulangan korupsi. 
Hal ini senada dengan yang disampaikan oleh Muladi \& Arief (1984: 92-93), sebagai berikut:

Sebagai salah satu bagian dari mata rantai penanggulangan kejahatan untuk mencapai kesejahteraan masyarakat itu, maka tahap penetapan pidana hemat kami justru harus merupakan tahap perencanaan yang matang mengenai kebijakan tindakan-tindakan apa yang seharusnya diambil dalam hal pemidanaan apabila terjadi suatu pelanggaran hukum. Dengan perkataan lain, tahap ini harus merupakan tahap perencanaan strategis di bidang pemidanaan yang diharapkan dapat memberi arah pada tahap-tahap berikutnya yaitu tahap penerapan pidana dan tahap pelaksanaan pidana.

Aparat penegak hukum dalam hal ini KPK, Kepolisian, Kejaksaan, dan pengadilan dalam memidana pelaku tindak pidana korupsi dengan demikian akan dipandu oleh Undang-Undang Tindak Pidana Korupsi sebagai dasar untuk melakukan pemidanaan terhadap seseorang (manusia maupun korporasi). Undang-Undang Tindak Pidana Korupsi telah menetapkan ketentuan hukum pidana materiil dan formal sebagai dasar untuk memidana pelaku tindak pidana korupsi. Salah satu norma hukum pidana materiil yang muncul adalah adanya unsur sifat melawan hukum materiil sebagai dasar untuk menyatakan adanya tindak pidana korupsi. Namun melalui Putusan Nomor 003/ PUU-IV/2006, sifat melawan hukum materiil dinyatakan bertentangan dengan UUD NRI 1945 dan tidak mempunyai kekuatan mengikatnya.

Hal tersebut dinyatakan secara tegas dalam amar putusan tersebut dengan menyatakan:

a. Penjelasan Pasal 2 ayat (1) Undang-
Undang Nomor 31 Tahun 1999 tentang
Pemberantasan Tindak Pidana Korupsi
sebagaimana telah diubah dengan Undang-
Undang Nomor 20 Tahun 2001 tentang
Perubahan Atas Undang-Undang Nomor 31 Tahun 1999 tentang Pemberantasan Tindak Pidana Korupsi (Lembaran Negara Republik Indonesia Tahun 2001 Nomor 134, Tambahan Lembaran Negara Republik Indonesia Nomor 4150) sepanjang frasa yang berbunyi: "Yang dimaksud dengan 'secara melawan hukum' dalam Pasal ini mencakup perbuatan melawan hukum dalam arti formal maupun dalam arti materiil, yakni meskipun perbuatan tersebut tidak diatur dalam peraturan perundangundangan, namun apabila perbuatan tersebut dianggap tercela karena tidak sesuai dengan rasa keadilan atau normanorma kehidupan sosial dalam masyarakat, maka perbuatan tersebut dapat dipidana" bertentangan dengan UUD NRI 1945.

b. Menyatakan Penjelasan Pasal 2 ayat (1) Undang-Undang Nomor 31 Tahun 1999 tentang Pemberantasan Tindak Pidana Korupsi sebagaimana telah diubah dengan Undang-Undang Nomor 20 Tahun 2001 tentang Perubahan Atas UndangUndang Nomor 31 Tahun 1999 tentang Pemberantasan Tindak Pidana Korupsi (Lembaran Negara Republik Indonesia Tahun 2001 Nomor 134, Tambahan Lembaran Negara Republik Indonesia Nomor 4150) sepanjang frasa yang berbunyi: "Yang dimaksud dengan 'secara melawan hukum'dalam Pasal ini mencakup perbuatan melawan hukum dalam arti formal maupun dalam arti materiil, yakni meskipun perbuatan tersebut tidak diatur dalam peraturan perundang-undangan, namun apabila perbuatan tersebut dianggap tercela karena tidak sesuai dengan rasa keadilan atau norma-norma 
kehidupan sosial dalam masyarakat, maka perbuatan tersebut dapat dipidana" tidak mempunyai kekuatan hukum mengikat.

Sebelum menyatakan putusannya sebagaimana diuraikan di atas, Mahkamah Konstitusi terhadap unsur melawan hukum berpendapat bahwa:

Menimbang bahwa selanjutnya yang perlu mendapat perhatian dan dipertimbangkan secara mendalam adalah kalimat pertama Penjelasan Pasal 2 ayat (1) Undang-Undang Pemberantasan Tindak Pidana Korupsi, yang juga dimohonkan pengujian oleh pemohon sebagaimana tertulis dalam petitum permohonannya meskipun pemohon tidak memfokuskan argumentasinya secara khusus terhadap bagian tersebut. Pasal 2 ayat (1) tersebut memperluas kategori unsur "melawan hukum", dalam hukum pidana, tidak lagi hanya sebagai formele wederrechtelijkheid melainkan juga dalam arti materiele wederrechtelijkheid. Penjelasan Pasal 2 ayat (1) kalimat bagian pertama tersebut berbunyi: "Yang dimaksud dengan secara melawan hukum' dalam pasal ini mencakup perbuatan melawan hukum dalam arti formal maupun dalam arti materiil, yakni meskipun perbuatan tersebut tidak diatur dalam peraturan perundang-undangan, namun apabila perbuatan tersebut dianggap tercela karena tidak sesuai dengan rasa keadilan atau norma-norma kehidupan sosial dalam masyarakat, maka perbuatan tersebut dapat dipidana";

Menimbang bahwa dengan bunyi penjelasan yang demikian, maka meskipun perbuatan tersebut tidak diatur dalam peraturan perundang-undangan secara formal, yaitu dalam pengertian yang bersifat onwetmatig, namun apabila menurut ukuran yang dianut dalam masyarakat, yaitu norma-norma sosial yang memandang satu perbuatan sebagai perbuatan tercela menurut norma sosial tersebut, di mana perbuatan tersebut dipandang telah melanggar kepatutan, kehati-hatian, dan keharusan yang dianut dalam hubungan orang-perorang dalam masyarakat maka dipandang bahwa perbuatan tersebut telah memenuhi unsur melawan hukum (wederrechtelijk). Ukuran yang dipergunakan dalam hal ini adalah hukum atau peraturan tidak tertulis. Rasa keadilan (rechtsgevoel), norma kesusilaan atau etik, dan norma-norma moral yang berlaku di masyarakat telah cukup untuk menjadi kriteria satu perbuatan tersebut merupakan tindakan yang melawan hukum, meskipun hanya dilihat secara materiil. Penjelasan dari pembuat undang-undang ini sesungguhnya bukan hanya menjelaskan Pasal 2 ayat (1) tentang unsur melawan hukum, melainkan telah melahirkan norma baru, yang memuat digunakannya ukuranukuran yang tidak tertulis dalam undangundang secara formal untuk menentukan perbuatan yang dapat dipidana. Penjelasan yang demikian telah menyebabkan kriteria perbuatan melawan hukum (Pasal 1365 KUHPerdata) yang dikenal dalam hukum perdata yang dikembangkan sebagai yurisprudensi mengenai perbuatan melawan hukum (onrechtmatigedaad), seolah-olah telah diterima menjadi satu ukuran melawan hukum dalam hukum pidana (wederrechtelijkheid). Oleh karena itu, apa yang patut dan yang memenuhi syarat moralitas dan rasa keadilan yang diakui dalam masyarakat, yang berbedabeda dari satu daerah ke daerah lain, akan mengakibatkan bahwa apa yang di satu daerah merupakan perbuatan yang melawan hukum, di daerah lain boleh jadi bukan merupakan perbuatan yang melawan hukum;

Menimbang bahwa berkaitan dengan pertimbangan di atas, Mahkamah Konstitusi dalam Putusan Nomor 005/PUU-III/2005 telah pula menguraikan bahwa sesuai dengan kebiasaan yang berlaku dalam praktik pembentukan perundang-undangan yang baik, yang juga diakui mengikat secara hukum, penjelasan berfungsi untuk menjelaskan substansi norma yang terdapat dalam pasal dan tidak menambahkan norma baru, apalagi memuat substansi yang sama sekali bertentangan dengan norma yang dijelaskan. Kebiasaan ini ternyata telah pula dikuatkan dalam Butir E Lampiran yang tak terpisahkan dari Undang-Undang Nomor 10 Tahun 2004 tentang Pembentukan Peraturan Perundang-undangan antara lain menentukan: 
a. Penjelasan berfungsi sebagai tafsiran resmi pembentuk peraturan perundang- undangan atas norma tertentu dalam batang tubuh. Oleh karena itu penjelasan hanya memuat uraian atau jabaran lebih lanjut norma yang diatur dalam batang tubuh. Dengan demikian penjelasan sebagai sarana untuk memperjelas norma batang tubuh, tidak boleh mengakibatkan terjadinya ketidakjelasan norma yang dijelaskan;

b. Penjelasan tidak dapat digunakan sebagai dasar hukum untuk membuat peraturan lebih lanjut;

c. Dalam penjelasan dihindari rumusan yang isinya memuat perubahan terselubung terhadap ketentuan perundang-undangan yang bersangkutan.

Keberadaan sifat melawan hukum dalam Penjelasan Pasal 2 ayat (1) Undang-Undang Tindak Pidana Korupsi, Mahkamah Konstitusi mengemukakan terdapat beberapa hal yang perlu dipertimbangkan terkait persoalan konstitusionalitasnya, antara lain:

a. Pasal28Dayat(1)mengakui dan melindungi hak konstitusional warga negara untuk memperoleh jaminan dan perlindungan hukum yang pasti, dengan mana dalam bidang hukum pidana diterjemahkan sebagai asas legalitas yang dimuat dalam Pasal 1 ayat (1) KUHP, bahwa asas tersebut merupakan satu tuntutan akan kepastian hukum di mana orang hanya dapat dituntut dan diadili atas dasar suatu peraturan perundang-undangan yang tertulis (lex scripta) yang telah lebih dahulu ada;

b. Hal demikian menuntut bahwa suatu tindak pidana memiliki unsur melawan hukum, yang harus secara tertulis lebih dahulu telah berlaku, yang merumuskan perbuatan apa atau akibat apa dari perbuatan manusia secara jelas dan ketat yang dilarang sehingga karenanya dapat dituntut dan dipidana, sesuai dengan prinsip nullum crimen sine lege stricta;

c. Konsep melawan hukum yang secara formal tertulis (formele wederrechtelijk), yang mewajibkan pembuat undangundang untuk merumuskan secermat dan serinci mungkin merupakan syarat untuk menjamin kepastian hukum (lex certa) atau yang dikenal juga dengan istilah bestimmtheitsgebot.

Mahkamah Konstitusi berkesimpulan bahwa konsep melawan hukum materiil (materiele wederrechtelijk), yang merujuk pada hukum tidak tertulis dalam ukuran kepatutan, kehati-hatian, dan kecermatan yang hidup dalam masyarakat, sebagai satu norma keadilan, adalah merupakan ukuran yang tidak pasti, dan berbedabeda dari satu lingkungan masyarakat tertentu ke lingkungan masyarakat lainnya. Sehingga apa yang melawan hukum di satu tempat mungkin di tempat lain diterima dan diakui sebagai sesuatu yang sah dan tidak melawan hukum, menurut ukuran yang dikenal dalam kehidupan masyarakat setempat, sebagaimana yang disampaikan Ahli Andi Hamzah, dalam persidangan. Oleh karenanya Penjelasan Pasal 2 ayat (1) UndangUndang Pemberantasan Tindak Pidana Korupsi kalimat pertama tersebut, merupakan hal yang tidak sesuai dengan perlindungan dan jaminan kepastian hukum yang adil yang dimuat dalam Pasal 28D ayat (1) UUD NRI 1945.

Penjelasan Pasal 2 ayat (1) Undang-Undang Pemberantasan Tindak Pidana Korupsi sepanjang mengenai frasa: "Yang dimaksud dengan 'secara 
melawan hukum' dalam pasal ini mencakup perbuatan-perbuatan melawan hukum dalam arti formal maupun dalam arti materiil, yakni meskipun perbuatan tersebut tidak diatur dalam peraturan perundang-undangan, namun apabila perbuatan tersebut dianggap tercela karena tidak sesuai dengan rasa keadilan atau normanorma kehidupan sosial dalam masyarakat, maka perbuatan tersebut dapat dipidana", harus dinyatakan bertentangan dengan UUD NRI 1945.

1. Mencermati pandangan Mahkamah Konstitusi, memperlihatkan adanya ketidaktepatan dalam menilai konstitusionalitas sifat melawan hukum materiil dalam Pasal 2 ayat (1) UndangUndang Tindak Pidana Korupsi. Berkenaan dengan hal tersebut terdapat beberapa hal yang perlu mendapatkan catatan, antara lain:

Mahkamah Konstitusi pada saat menguji konstitusionalitas unsur melawan hukum materiil dalam Pasal 2 ayat (1) Undang-Undang Tindak Pidana Korupsi, seolah-olah batu ujinya didasarkan pada asas legalitas yang terdapat dalam Pasal 1 ayat (1) KUHP. Apa yang terkandung dalam Pasal 1 ayat (1) KUHP dijadikan tolok ukur untuk menilai konstitusionalitas Pasal 2 ayat (1) Undang-Undang Tindak Pidana Korupsi.

Hal ini terlihat pada pandangan Mahkamah Konstitusi yang berpendapat bahwa Pasal 28D ayat (1) mengakui dan melindungi hak konstitusional warga negara untuk memperoleh jaminan dan perlindungan hukum yang pasti. Dengan mana dalam bidang hukum pidana diterjemahkan sebagai asas legalitas yang dimuat dalam Pasal 1 ayat (1) KUHP, bahwa asas tersebut merupakan satu tuntutan akan kepastian hukum di mana orang hanya dapat dituntut dan diadili atas dasar suatu peraturan perundang-undangan yang tertulis (lex scripta) yang telah lebih dahulu ada. Di sini memperlihatkan bahwa Pasal 1 ayat (1) KUHP merupakan penjabaran lebih lanjut dari Pasal 28D ayat (1) UUD NRI 1945. Bahkan lebih dari itu, asas legalitas formal yang mensyaratkan sifat melawan hukum formal yang terdapat di dalam Pasal 1 (1) KUHP jadi pertimbangan utama dalam memutus.

Menjadi pertanyaan, bukankah KUHP yang saat ini berlaku tidak dibangun berdasarkan apa yang terkandung dalam Pancasila dan UUD NRI 1945. Bahkan Piepers menyatakan "Met die Code Penal (baca W.v.S.Ned.) ging het als een broek die eerst door vader wordt gedragen, dan overgaat op den oudsten en vervolgens met een lap er op, op den tweede zoon". Dialihbahasakan secara bebas (oleh Sahetapy, pen.) "Code Penal (baca KUHP) bagaikan sebuah celana yang dulu dipakai oleh ayah, kemudian beralih kepada anak yang sulung dan selanjutnya dengan tambalan sepotong kain diteruskan kepada anak yang kedua". Pernyataan ini menjadi wajar, karena seperti yang dikatakan oleh Sahetapy '(KUHP dapat, pen.) dikatakan juga dari Perancis dan tidak saja Belanda, sebab Belanda pada hakikatnya mengambil alih dari Perancis yaitu Code Penal c.q. W.v.S.Ned., di mana Perancis pernah menjajah Belanda' (Sahetapy, 2012: 120).

Berdasarkan pada Pasal II Aturan Peralihan UUD NRI 1945 sebelum amandemen yang selanjutnya pasca 
amandemen UUD NRI 1945, dasar yuridis berlakunya KUHP dapat ditemukan dalam Pasal I Aturan Peralihan yang menyatakan: "Segala peraturan perundang-undangan yang ada masih tetap berlaku selama belum diadakan yang baru menurut UndangUndang Dasar ini”. Sehingga tidak dapat dikatakan bahwa Pasal 1 ayat (1) KUHP merupakan penjabaran lebih lanjut dari Pasal 28D ayat (1) UUD NRI 1945.

Terkait dengan adanya pembatalan norma dalam Pasal 2 ayat (1) UndangUndang Tindak Pidana Korupsi dengan mendasarkan pada Pasal 1 ayat (1) KUHP, perlu untuk diperhatikan ketentuan Pasal 24C ayat (1) UUD NRI 1945 menyatakan: "Mahkamah Konstitusi berwenang mengadili pada tingkat pertama dan terakhir yang putusannya final untuk menguji undang-undang terhadap Undang-Undang Dasar..." ketentuan tersebut menjadi dasar konstitusionalitas Mahkamah Konstitusi dalam melakukan judicial review.

Indrati mengungkapkan, penggunaan istilah judicial review lebih dikenal dalam masyarakat di Indonesia, sebenarnya lahir dari negara yang menganut asas sistem pemisahan kekuasaan (trias politica), di mana Amerika Serikat sebagai negara yang terkenal menggunakannya prinsip tersebut (Indrati, 2000: 105). Berkenaan dengan hal tersebut, Asshidiqqie menyatakan dalam kajian toetsingsrecht (hak menguji) dalam istilah kepustakaan Belanda, hak menguji tersebut kemudian dibagi dua menjadi hak menguji formal (formele toetsubfsrecht) dan hak menguji material (materiele toetsingsrecht) (Asshidiqqie, 2006: 2).
Pengujianundang-undang merupakan suatu wewenang untuk menilai apakah suatu peraturan perundang-undangan isinya sesuai atau bertentangan dengan peraturan yang lebih tinggi derajatnya, serta apakah suatu kekuasaan tertentu berhak mengeluarkan suatu peraturan tertentu. Norma dalam Pasal 24C memberikan pedoman mendasar dalam melakukan judicial review, di mana UUD NRI 1945 menjadi dasar untuk memvalidasi norma yang terdapat dalam undang-undang. Ketentuan dalam Pasal 24C ayat (1) UUD NRI 1945 diperkuat dengan Pasal 10 Undang-Undang Mahkamah Konstitusi yang menyatakan hal yang sama.

Sistem pengujian peraturan perundang-undangan di Indonesia mengisyaratkan, bahwa suatu peraturan perundang-undangan dapat digugat atau dimohonkan pengujiannya karena:

a. Pembentukan undang-undang tidak memenuhi ketentuan berdasarkan UUD NRI 1945;

b. Materi muatan dalam ayat, pasal, dan/atau bagian undang-undang bertentangan dengan UUD NRI 1945; atau

c. Materi muatan dalam ayat, pasal, dan/ atau bagian peraturan perundangundangan di bawah undang-undang bertentangan dengan undangundang.

Hal di atas menunjukkan bahwa pengujian terhadap materi muatan pada Pasal 2 ayat (1) Undang-Undang Tindak Pidana Korupsi harus didasarkan pada 
norma yang terkandung dalam UUD NRI 1945. Sehingga tidaklah tepat apabila Pasal 1 ayat (1) KUHP dijadikan batu ujinya. Pandangan ini senada dengan yang disampaikan oleh Arief, pengujian Undang-Undang Tindak Pidana Korupsi seharusnya dilandaskan pada asas (termasuk asas kepastian hukum) yang ada dalam konstitusi (UUD NRI 1945), bukan asas yang ada dalam KUHP (Arief, 2014: 14).

2. Putusan Mahkamah Konstitusi lebih berorientasi mempertimbangkan kepastian hukum (legal certainty) dalam penanggulangan tindak pidana korupsi. Hal ini dapat diidentifikasi dengan diterimanya asas legalitas sebagai alat untuk menguji Pasal 2 ayat (1) UndangUndang Tindak Pidana Korupsi. Secara historis, gagasan legalitas yang mengklaim dapat memberikan kepastian hukum dalam penegakan hukum, khususnya dalam ranah hukum pidana. Jika ditelusuri filosofis dan historis, itu adalah sebuah gagasan yang lahir berkat gagasan legisme (Manullang, 2017: 9).

Terkait dengan asas legalitas, Termorschuizen mengemukakan: "the view that lex scripta can be certa, that is to say certain, in the sense of unambiguous, cannot be maintained. There is no such thing as a legal provision which is clear and unambiguous in all circumstances" (Arief, 2014: 16).

Kepastian hukum sejatinya merupakan bagian dari tujuan yang harus diwujudkan oleh institusi bernama hukum (termasuk oleh putusan hakim). Radbruch menentang aliran positivisme hukum yang hanya menjunjung nilai kepastian sebagai satu-satunya tujuan hukum. Menurutnya ada tiga nilai dasar dari hukum, yakni keadilan (gerechtigkeit), kemanfaatan (zweckmässigkeit), dan kepastian (rechtssicherheit). Pendapat Radbruch mengenai nilai-nilai yang harus diakomodir oleh hukum nampaknya sudah termasyhur, sehingga banyak dijadikan rujukan dalam berbagai literatur, di antaranya sebagai berikut:

Radbruch's pre-war work, however, by no means denotes indifference to values. The concept of law presented in his Rechtsphilosophie is indeed value-related: Radbruch finds that law can only be defined as the reality striving towards "the idea of law," which is justice (Gerechtigkeit) (Radbruch 1950b, 91-3). But the idea of justice Radbruch is referring to - an objective idea of distributive justice, essentially meaning equalitydoes not fully exhaust the concept of law. To complete the concept of law, Radbruch adds two elements: purposiveness (Zweckmässigkeit) and legal certainty (Rechtssicherheit) (Haldemann, 2005).

Selain Frank, pendapat Radbruch pun pernah dielaborasi oleh Leawoods (2000), sebagai berikut:

To complete the concept of law Radbruch uses three general precepts: purposiveness, justice, and legal certainty. Therefore, Radbruch defines law as "the complex of general precepts for the living-together of human beings" whose ultimate idea is oriented toward justice or equality.

Leawoods selanjutnya menjelaskan secara jelas mengenai perkembangan pemikiran Radbruch mengenai nilai-nilai 
yang harus diakomodir oleh hukum. Pada awalnya menurut Radbruch, nilai utama satu-satunya dari hukum adalah keadilan. Selanjutnya dalam perjalanannya, nilai dasar dari hukum menurutnya belum lengkap tanpa kemanfaatan dan kepastian. Sehingga nilai-nilai yang harus dipenuhi oleh hukum adalah keadilan, kepastian, dan kemanfaatan. Selanjutnya menurut Radbruch, ketika ada pertentangan di antara ketiga nilai tersebut, maka kepastian yang harus diutamakan. Akan tetapi tidak lama kemudian, Radbruch menganulir pernyataannya bahwa keadilanlah yang harus diutamakan. Berikut ini dikutipkan kembali narasi otentiknya di bawah ini:

Radbruch establishes the foundation for his theory in his 1932 work, Rechtsphilosophie. He finds that law, as a cultural concept, "is the reality the meaning of which is to serve the legal value, the idea of law." Radbruch argues that the idea of law may only be Justice....... Radbruch finds that although the idea of law is Justice, this alone does not fully exhaust the concept of law. Justice, he says, "leaves open the two questions, whom to consider equal or different, and how to treat them." To complete the concept of law Radbruch uses three general precepts: purposiveness, justice, and legal certainty.... Certainly, the conflict between legal certainty and justice or between legal certainty and purposiveness is easy to imagine...... In this situation alone, the emphasis on legal certainty is greatest. Although a law may be unjust in its content, it nonetheless serves at least one purpose, legal certainty........ Radbruch rejects his earlier assertion that legal certainty was the primary role of the judge and now asserts that the judge must decide first in accordance with Justice (Leawoods, 2000).
Mencermati apa yang disampaikan oleh Radbruch, sehingga pada saat Mahkamah Konstitusi dihadapkan pada perdebatan apakah akan memilih keadilan atau kepastian, maka the judge must decide first in accordance with justice. Radbruch menyadari bahwa keadilan merupakan salah satu nilai hukum, selain kemanfaatan dan kepastian hukum. Ketiga nilai hukum tersebut tidak selalu menyatu secara harmonis di dalam hukum. Hukum yang bertentangan dengan nilai-nilai tersebut tidak memiliki keabsahan (Wahyudi, 2015: 273).

Putusan Nomor 003/PUU-IV/2006 hanya mengakui unsur sifat melawan hukum formal yang berorientasi pada penciptaan kepastian hukum, dan menolak sifat melawan hukum materiil yang orientasinya adalah menciptakan keadilan di masyarakat. Berkenaan dengan orientasi nilai yang hendak dilindungi oleh unsur sifat melawan hukum formal dan materiil disampaikan oleh Remmelink dan Arief. Remmelink mengungkapkan konsep melawan hukum yang secara formal tertulis (formele wederrechtelijk), yang mewajibkan pembuat undang-undang untuk merumuskan secermat dan serinci mungkin merupakan syarat untuk menjamin kepastian hukum (lex certa) atau dikenal juga dengan istilah bestimmheitsgebot.

Secara teoritis terdapat dua fungsi dari ajaran sifat melawan hukum materiil, yaitu: (a) ajaran sifat melawan hukum materiil dalam fungsinya yang positif, yaitu suatu perbuatan meskipun oleh peraturan perundang-undangan tidak ditentukan sebagai melawan hukum, tetapi jika 
menurut penilaian masyarakat perbuatan tersebut bersifat melawan hukum, perbuatan yang dimaksud tetap merupakan perbuatan yang bersifat melawan hokum; dan (b) ajaran sifat melawan hukum materiil dalam fungsinya yang negatif, yaitu suatu perbuatan meskipun menurut peraturan perundang-undangan merupakan perbuatan yang bersifat melawan hukum, tetapi jika menurut penilaian masyarakat perbuatan tersebut tidak bersifat melawan hukum, perbuatan yang dimaksud adalah perbuatan yang tidak bersifat melawan hukum (Saleh, 1987: 18-19).

Terkait dengan hal tersebut, Arief mengungkapkan apa yang terkandung dalam ajaran sifat melawan hukum materiil yang terdapat dalam UndangUndang Tindak Pidana Korupsi, dengan mengatakan sebagai berikut:

Menganut ajaran sifat melawan hukum materiil dalam fungsinya yang positif dengan kritetria bahwa perbuatan yang tidak diatur dalam peraturan perundang-undangan itu dipandang sebagai "perbuatan tercela" karena tidak sesuai dengan rasa keadilan, atau tidak sesuai dengan norma-norma kehidupan sosial dalam masyarakat (Arief, 2014: 11).

Menarik untuk diperhatikan bahwa kepastian hukum telah banyak dikritik oleh berbagai kalangan, antara lain:

a. Samphord menyatakan bahwa kepastian hukum itu bukan suatu hal yang nyata, melainkan suatu keinginan untuk melihat hukum sebagai suatu institut yang penuh dengan kepastian. Samphord melihat hukum banyak diisi dengan ketidakpastian (Rahardjo, 2010: 177).

b. Dworkin, mengemukakan: "Foremost amongst modern critics of positivism, levels an interesting dilemma. Within law, there exist certain cases where the law is silent. This is referred to as indeterminacy, when the law gives conflicting or no guidance to a particular situation" (Chambers, 2011).

c. Shidarta, apa yang diharapkan oleh legisme (baca: positivisme, pen.) dinyatakan sebagai sesuatu yang hanya sebatas asumsi. Selanjutnya beliau menegaskan, het recht hink achter de feiten aan: hukum selalu berjalan tertatih-tatih di belakang peristiwa konkret. Oleh sebab itu, cepat atau lambat, undang-undang akan tertinggal oleh fakta. Jurang ketertinggalan itu kian melebar seiring dengan berubahnya tatanan sosial tempat hukum itu hidup di dalam alam kenyataannya. Di sinilah terjadi legal gap antara hukum di atas kertas (law in the books) dan hukum yang hidup dalam kenyataan (law in action; the living law).

3. Putusan Mahkamah Konstitusi telah menghilangkan keberlakuan hukum yang tidak tertulis sebagai sumber untuk menyatakan suatu perbuatan bersifat melawan hukum. Hal ini ditandai dengan materiele wederrechtelijk yang dinyatakan bertentangan dengan UUD NRI 1945 dan dinyatakan tidak berlaku mengikat. Dengan demikian suatu perbuatan dipandang 
melawan hukum apabila bertentangan dengan law as it is.

Pandangan yang demikian tentunya bertentangan dengan konstitusi dan berbagai peraturan perundang-undangan yang berlaku. Pertama, Pasal 18B ayat (2) UUD NRI 1945 menyatakan: "Negara mengakui dan menghormati kesatuankesatuan masyarakat hukum adat beserta hak-hak tradisionalnya sepanjang masih hidup dan sesuai dengan perkembangan masyarakat dan prinsip Negara Kesatuan Republik Indonesia, yang diatur dalam undang-undang." Diakuinya keberadaan masyarakat hukum adat, secara tidak langsung mengakui keberadaan hukum adat atau hukum yang tidak tertulis sebagai sumber hukum. Arief menyatakan tidak diakuinya (diharamkannya) hukum tidak tertulis dengan bertolak dari asas legalitas (Pasal 1 KUHP), sangat tidak relevan dengan jiwa/semangat UUD NRI 1945.

Hukum tidak tertulis yang diharamkan pada masa lahirnya asas legalitas (zaman revolusi Perancis) adalah hukumnya raja/ penguasa (yang tidak tertulis). Hal ini tidak dapat disamakan dengan hukum tidak tertulis di Indonesia, yang pada hakikatnya merupakan hukumnya rakyat atau hukum yang hidup di masyarakat (Arief, 2014: 15).

Kedua, dalam Undang-Undang Darurat Nomor 1 Tahun 1951 tentang Tindakan-Tindakan Sementara untuk Menyelenggarakan Kesaturan Susunan Kekuasaan dan Acara PengadilanPengadilan Sipil, pada Pasal 5 ayat (3) huruf b menyatakan: "bahwa suatu perbuatan yang menurut hukum yang hidup harus dianggap perbuatan pidana, akan tetapi tiada bandingnya dalam Kitab Hukum Pidana Sipil, maka dianggap diancam dengan hukuman yang tidak lebih dari tiga bulan penjara dan/atau denda lima ratus rupiah, yaitu sebagai hukuman pengganti bilamana hukuman adat yang dijatuhkan tidak diikuti oleh pihak terhukum dan penggantian yang dimaksud dianggap sepadan oleh hakim dengan besar kesalahan yang terhukum". Selanjutnya dinyatakan pula "suatu perbuatan yang menurut hukum yang hidup harus dianggap perbuatan pidana dan yang ada bandingnya dalam Kitab Hukum Pidana Sipil, maka dianggap diancam dengan hukuman yang sama dengan hukuman bandingnya yang paling mirip kepada perbuatan pidana itu."

Ketiga, Undang-Undang Nomor 48 Tahun 2009 tentang Kekuasaan Kehakiman pada Pasal 5 ayat (1) menyatakan: bahwa hakim dan hakim konstitusi wajib menggali, mengikuti, dan memahami nilainilai hukum dan rasa keadilan yang hidup dalam masyarakat. Ketentuan tersebut dimaksudkan agar putusan hakim dan hakim konstitusi sesuai dengan hukum dan rasa keadilan masyarakat. Kewajiban yang diamanatkan melalui pasal tersebut menegaskan bahwa hakim dan hakim konstitusi harus menggali, mengikuti, dan memahami nilai-nilai hukum dan rasa keadilan yang hidup dalam masyarakat. Pasal ini dengan demikian memungkinan bagi hakim dan hakim konstitusi untuk menggunakan hukum yang tidak tertulis sebagai dasar untuk memutus. Dalam konteks pemidanaan, maka nilai-nilai hukum dan rasa keadilan yang hidup 
dalam masyarakat dapat menjadi sumber untuk menyatakan suatu perbuatan bersifat melawan hukum. Artinya melegitimasi keberadaan asas melawan hukum materiil. Hanya diakuinya sumber hukum yang tertulis untuk menyatakan suatu perbuatan bersifat melawan hukum menandakan Mahkamah Konstitusi dipandu oleh aliran positivisme hukum.

Hal ini terlihat dalam pemaknaan hukum atau aspek ontologi sebagai sumber yang digunakan dalam menyatakan suatu perbuatan bersifat melawan hukum yang hanya didasarkan pada norma hukum tertulis. Shidarta menjelaskan "positivism hukum dalam definisinya yang paling tradisional tentang hukum, memaknainya sebagai norma-norma positif dalam peraturan perundang-undangan " (Shidarta, 2013: 198). Selain itu, kepastian hukum menjadi orientasi utama dalam menolak keberadaan unsur sifat melawan hukum, juga menunjukan aspek aksiologi yang diutamakan adalah kepastian hukum. Kepastian hukum merupakan tujuan utama yang harus diwujudkan oleh hukum sebagaimana diyakini oleh penganut aliran positivisme hukum.

Aspek aksiologis yang diperjuangkan positivisme hukum adalah kepastian hukum. Dengan mengambil sumber formal hukum berupa perundang-undangan, diyakini bahwa ihwal ini dapat diwujudkan. Asas legalitas merupakan roh dari upaya pengejaran kepastian hukum tersebut. Asas ini oleh von Feuerbach dirumuskan dalam adagium "no punishment without law, no punishment without crime, no crime without punishment (nulla poena sine lege, nulla poena sine crimine, nullum crimen sine poena) (Shidarta, 2013: 200).”

Lahirnya Putusan Nomor 003/PUUIV/2006 yang membatalkan sifat melawan hukum materiil dikarenakan dipandu oleh aliran positivisme hukum. Unsur sifat melawan hukum materiil sebagai dasar untuk menyatakan suatu perbuatan bersifat melawan hukum, dengan demikian sebetulnya sejalan dengan Pasal 28D ayat (1) UUD NRI 1945 dan berbagai peraturan perundang-undangan yang berlaku. Lebih lanjut sebetulnya ajaran sifat melawan hukum materiil di Indonesia sebetulnya telah ada dan digunakan dalam tataran praktik peradilan.

Mengenai hal itu Wibowo \& Nurhayati menguraikan penggunaan sifat melawan hukum materiil sebagai berikut:

Jika diperhatikan, penerapan ajaran sifat melawan hukum materiil di Indonesia sendiri oleh Mahkamah Agung, baik sebelum maupun sesudah dibentuk dan diberlakukan Undang-Undang Tindak Pidana Korupsi 2001, telah menerapkan dua ajaran sifat melawan hukum materiil, baik dalam fungsi positif maupun dalam fungsi negatif. Contoh penerapan ajaran sifat melawan hukum materiil dalam fungsi negatif oleh Mahkamah Agung pada putusan perkara tindak pidana korupsi atas nama Machrus Effendi tertanggal 8 Januari 1966, Reg. Nomor 42 $\mathrm{K} / \mathrm{Kr} / 1965$ dan perkara tindak pidana korupsi atas nama Ir. Otjo Danuatmadja tertanggal 20 Maret 1977, Reg. Nomor 81 K/ Kr/1973. Sedangkan di sisi lain, Mahkamah Agung juga telah menerapkan ajaran sifat melawan hukum materiil dalam fungsi positif pada perkara tindak pidana korupsi atas nama terdakwa Drs. R. S Natalegawa pada putusan 
Nomor 275 K/Pid/1983 tanggal 29

Desember 1983, dan pada kasus pemberian kredit oleh Bank Mandiri yaitu E.C.W Neloe walaupun telah ada putusan judicial review Mahkamah Konstitusi pada saat pemeriksaan berlangsung (Wibowo \& Nurhayati, 2015: 355).

Senada dengan sebagaimana disebutkan di atas, Sudharmawatiningsih dalam tulisannya, terdapat yurisprudensi tetap Mahkamah Agung yang telah menganut sifat melawan hukum materiil dalam perkara korupsi, yaitu:

1. Putusan Mahkamah Agung RI Nomor 42K/Kr/1965, tanggal 8 Januari 1965

"Bahwa suatu tindakan pada umumnya hilang sifat melawan hukumnya, bukan hanya berdasarkan pada ketentuan perundang-undangan, melainkan juga berdasarkan pada asas-asas keadilan, asas-asas hukum yang tidak tertulis dan bersifat umum, misalnya terpenuhinya tiga faktor yakni: negara tidak dirugikan, kepentingan umum dilayani; dan terdakwa sendiri tidak mendapat untung."

2. Putusan Mahkamah Agung RI Nomor $275 \mathrm{~K} / \mathrm{Pid} / 1983$, tanggal 15 Desember 1983

"Bahwa menurut kepatutan dalam masyarakat khususnya dalam perkara- perkara tindak pidana korupsi, apabila seorang pegawai negeri menerima fasilitas yang berlebihan serta keuntungan lainnya dari seorang lain dengan maksud menggunakan kekuasaannya atau wewenangnya yang melekat pada jabatannya secara menyimpang, hal itu sudah merupakan "perbuatan melawan hukum." Karena menurut kepatutan perbuatan itu merupakan perbuatan yang tercela atau perbuatan yang merusak perasaan masyarakat banyak" (Sudharmawatiningsih, 2007: 12).
Sebetulnya yang menjadi permasalahan adalah perumusan norma sifat melawan hukum materiil yang dimuat dalam penjelasan pasal, dan bukan dalam batang tubuh atau pasal di UndangUndang Tindak Pidana Korupsi. Ketentuan Penjelasan Pasal 2 ayat (1) UndangUndang Tindak Pidana Korupsi saat ini memunculkan norma berupa:

"Yang dimaksud dengan secara melawan hukum dalam Pasal ini mencakup perbuatan melawan hukum dalam arti formal maupun dalam arti materiil, yakni meskipun perbuatan tersebut tidak diatur dalam peraturan perundang-undangan, namun apabila perbuatan tersebut dianggap tercela karena tidak sesuai dengan rasa keadilan atau normanorma kehidupan sosial dalam masyarakat, maka perbuatan tersebut dapat dipidana. Dalam ketentuan ini, kata dapat sebelum frasa merugikan keuangan negara atau perekonomian negara menunjukkan bahwa tindak pidana korupsi merupakan delik formal, yaitu adanya tindak pidana korupsi cukup dengan dipenuhinya unsur-unsur perbuatan yang sudah dirumuskan bukan dengan timbulnya akibat."

Standar regulatif yang sudah berlaku dalam dua rezim undang-undang yang mengatur pembentukan peraturan perundang-undangan, yakni UndangUndang Nomor 10 Tahun 2004 tentang Pembentukan Peraturan PerundangUndangan yang kemudian diganti dengan Undang-Undang Nomor 12 Tahun 2011 tentang Pembentukan Peraturan PerundangUndangan.

Berikut ini beberapa pedoman penting terkait dengan perumusan penjelasan sebuah undang-undang yang 
terdapat dalam Undang-Undang Nomor 12 Tahun 2011, antara lain:

a. Penjelasan berfungsi sebagai tafsir resmi pembentuk peraturan perundang-undangan atas norma tertentu dalam batang tubuh. Oleh karena itu, penjelasan hanya memuat uraian terhadap kata, frasa, kalimat atau padanan kata/istilah asing dalam norma yang dapat disertai dengan contoh. Penjelasan sebagai sarana untuk memperjelas norma dalam batang tubuh tidak boleh mengakibatkan terjadinya ketidakjelasan dari norma yang dimaksud.

b. Penjelasan tidak dapat digunakan sebagai dasar hukum untuk membuat peraturan lebih lanjut dan tidak boleh mencantumkan rumusan yang berisi norma.

c. Penjelasan tidak menggunakan rumusan yang isinya memuat perubahan terselubung terhadap ketentuan peraturan perundangundangan.

Berdasarkan pertimbangan di atas, maka sebetulnya Penjelasan Pasal 2 ayat (1) UndangUndang Tindak Pidana Korupsi seharusnya direvisi dengan memasukkan norma yang terkandung di dalamnya ke dalam rumusan pasal, karena kerangka regulasi yang ada saat ini menegaskan bahwa penjelasan tidak boleh mencantumkan rumusan yang berisi norma.

\section{KESIMPULAN}

Berdasarkan pembahasan apabila dibaca, dipahami, dan ditelusuri secara mendalam, maka dapat dikemukakan simpulan dalam tulisan ini adalah Mahkamah Konstitusi melalui Putusan Nomor 003/PUU-IV/2006 menyatakan bahwa Pasal 2 ayat (1) Undang-Undang Tindak Pidana Korupsi dinyatakan bertentangan dengankonstitusi dan tidak berlaku mengikat. Ini menandakan Mahkamah Konstitusi memandang unsur sifat melawan hukum materiil yang terkandung di dalam Penjelasan Pasal 2 ayat (1) Undang-Undang Tindak Pidana Korupsi inkonstitusional.

Pertimbangan yang disampaikan oleh Mahkamah Konstitusi sebagai dasar menyatakan tidak konstitusionalnya sifat melawan hukum materiil tidaklah tepat. Terhadap hal tersebut terdapat beberapa catatan kritis. Pertama, Mahkamah Konstitusi telah keliru dalam usahanya memvalidasi Pasal 2 ayat (1) UndangUndang Tindak Pidana Korupsi dengan menguji berdasarkan asas legalitas yang terdapat dalam Pasal 1 ayat (1) KUHP. Padahal prinsipnya pengujian yang dilakukan oleh Mahkamah Konstitusi adalah menguji undang-undang terhadap UUD NRI 1945. Hal ini ditegaskan dalam Pasal 24C ayat (1) UUD NRI 1945.

Kedua, putusan Mahkamah Konstitusi yang berorientasi pada asas legalitas yang hanya mengutamakan rechtssicherheit telah mengesampingkan keberadaan gerechtigkeit dan zweckmässigkeit. Ketiga, tidak diakuinya sifat melawan hukum materiil menandakanmeniadakan eksistensi hukum yang hidup di masyarakat sebagai sumber hukum untuk menyatakan suatu perbuatan bersifat melawan hukum.

Hal ini bertentangan dengan mandat Pasal 18B ayat (2) UUD NRI 1945 dan berbagai peraturan perundang-undangan yang berlaku, seperti Undang-Undang Darurat Nomor 1 Tahun 1951 tentang Tindakan-Tindakan Sementara 
untuk Menyelenggarakan Kesatuan Susunan Kekuasaan dan Acara Pengadilan-Pengadilan Sipil, dan Undang-Undang Nomor 48 Tahun 2009 tentang Kekuasaan Kehakiman. Lahirnya Putusan Nomor 003/PUU-IV/2006 yang membatalkan sifat melawan hukum materiil dikarenakan dipandu oleh aliran positivisme hukum. Mencermati hal tersebut di atas, sebenarnya Pasal 2 ayat (1) Undang-Undang Tindak Pidana Korupsi sejalan dengan konstitusi, namun kebijakan formulasinya yang tidak tepat karena dirumuskan dalam penjelasan pasal dan bukan dalam batang tubuh. Hal ini didasarkan pada prinsip bahwa penjelasan tidak boleh mencantumkan rumusan yang berisi norma.

\section{SARAN}

Mahkamah Konstitusi merupakan salah satu lembaga negara yang melakukan kekuasaan kehakiman yang merdeka untuk menyelenggarakan peradilan guna menegakkan hukum dan keadilan. Artinya pengujian undang-undang terhadap UUD NRI 1945 harus berorientasi pada penciptaan keadilan dan bukan hanya kepastian, terlebih Pasal 28D ayat (1) menekankan pada kepastian hukum yang adil dan bukan pada "kepastian." Tentu makna kepastian hukum yang adil sungguh berbeda dengan kepastian. Selanjutnya dalam mengadakan judicial review perlu untuk diperhatikan ketentuan Pasal 24C UUD NRI 1945 jo. Pasal 10 Undang-Undang Mahkamah Konstitusi yang tegas menetapkan pengujian yang dilakukan adalah undang-undang terhadap UUD NRI 1945.
Arief, B.N. (2012). Kebijakan formulasi ketentuan pidana dalam peraturan perundang-undangan. Semarang: Pustaka Magister. . (2014). Bunga rampai kebijakan hukum pidana: Perkembangan penyusunan konsep KUHP baru. Jakarta: Kencana.

Asshidiqqie, J. (2006). Hukum acara pengujian undang-undang. Jakarta: Konpress.

Begovic, B. (2005, Maret 21). Corruption: Concepts, types, causes, \& consequences. Washington: Center for International Private Enterprise.

Chambers, J.B. (2011). Legal positivism: An analysis. Undergraduate Honors Theses. Paper 79.

Haldemann, F. (2005, Juni). Gustav Radbruch vs. Hans Kelsen: A debate on Nazi Law. Ratio Juris, 18(2), (162-78).

Hiariej, E.O.S. (2016). Prinsip-prinsip hukum pidana. Yogyakarta: Cahaya Atma Pustaka.

Indrati, M.F. (2000). Masalah hak uji terhadap peraturan perundang-undangan dalam teori perundang-undangan dalam teori perundangundangan. Seri Buku Ajar. Jakarta: Fakultas Hukun Universitas Indonesia.

Lapenna, I. (2000). Soviet penal policy. Diakses dari www.kehlet.com and Birthe Lapenna.

Leawoods, H. (2000). Gustav Radbruch: An extraordinary legal philosopher. Journal of Law and Policy, 2, 489.

Manullang, E.F.M. (2017). Legisme, legalitas \& kepastian hukum. Jakarta: Kencana.

Muladi \& Arief, B.N. (1984). Teori-teori \& kebijakan pidana. Bandung: Alumni.

Rahardjo, S. (2010). Kultur para profesional, dalam 
penegakan hukum progresif. Jakarta: Kompas.

Sahetapy, J.E. (2012). Reformasi hukum harus mengejawantahkan Pancasila. Bunga Rampai: Dialektika Pembaruan Sistem Hukum Indonesia. Jakarta: Sekretariat Jenderal Komisi Yudisial.

Saleh, R. (1987). Sifat melawan hukum dari perbuatan hukum pidana. Jakarta: Aksara Baru.

Shidarta. (2013). Hukum penalaran \& penalaran hukum. Yogyakarta: Genta Publishing.

Sudharmawatiningsih. (2007, Oktober). Sifat melawan hukum materiil dalam tindak pidana korupsi (Respon terhadap putusan Mahkamah Konstitusi). Jurnal Hukum dan Dinamika Masyarakat, 5(1), 11-20.

United Nations. (2004, September). Handbook on practical anti-corruption measures for prosecutors \& investigators. Vienna.

Wahyudi, M.I. (2015, Desember). Penegakan keadilan dalam kewarisan beda agama: Kajian lima penetapan \& dua putusan pengadilan agama dalam perkara waris beda agama. Jurnal Yudisial, 8(3), 269-288.

Wibowo, S., \& Nurhayati, R. (2015). Perbedaan pandangan ajaran sifat melawan hukum materiil tindak pidana korupsi. Padjadjaran Jurnal Ilmu Hukum, 2(2), 351-369.

Wignjosoebroto, S. (2002). Hukum paradigma, metode \& dinamika masalahnya. Jakarta: HUMA. 